УДК 551.733.1(474)

Silvi MÄGI, Viive VIIRA, Helje ARU

\title{
ON THE CORRELATION OF THE TREMADOCIAN AND ARENIGIAN BOUNDARY BEDS IN THE EAST BALTIC
}

In the East Baltic as over the vast area of the East-European Platform the Tremadocian/Arenigian boundary is connected with the rocks rich in glauconite. There have been different suggestions to define the boundary the base or top or somewhere inside glauconitic beds. The present paper deals with the outcrop sections of the boundary beds in the North-Estonia-Ladoga clint area, for comparison we have used the Serebryaniki core from the Moscow district and the Stora Backor section from Sweden (according to Lindström, 1954, 1971a and Tjernvik, 1956) (Figs 1, 2).

Fig. 2 shows a general lithology of the boundary beds in these sections - the Scandinavian and Moscow district ones are represented by deeper water facies, the East Baltic ones by shallower shelf deposits which are less clayey in composition and there occur less frequently graptolites and partly trilobites most often used earlier for correlation. Our study is based mainly on conodonts.

The sequence of the main stratigraphic units made use in the paper is as follows (from top):

\begin{tabular}{l|ll}
\hline Regional stages & Formations & Members \\
\hline Volkhov & Toila & Saka \\
\cline { 3 - 3 } & & Päite \\
\cline { 2 - 3 } Latorp & Leetse & $\begin{array}{l}\text { Mäeküla } \\
\text { Joa } \\
\text { Klooga }\end{array}$ \\
\hline
\end{tabular}

Varangu

Fig. 1. Map showing location of the sections, given in Fig. 2. (SB - Stora Backor, K - Keila-Joa, V - Varangu, L Lava, S - Serebryaniki). 1 area of the Tremadocian and Arenigian epicontinental deposits; 2 - outcrop areas; 3 boring.

\section{Varangu}

Türisalu (part)

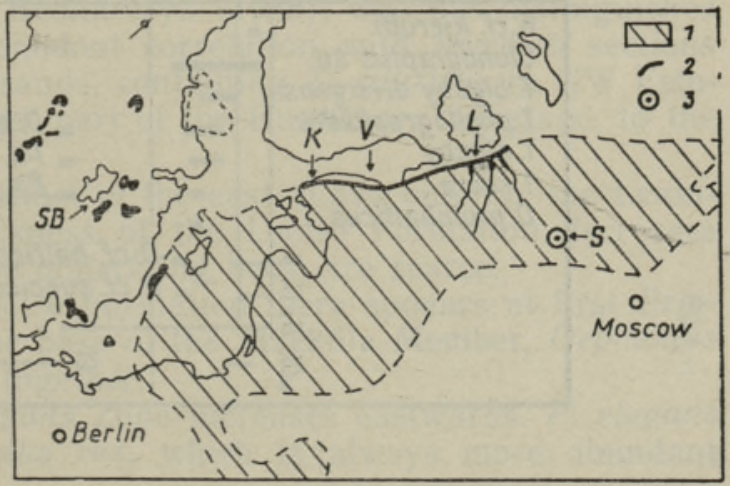




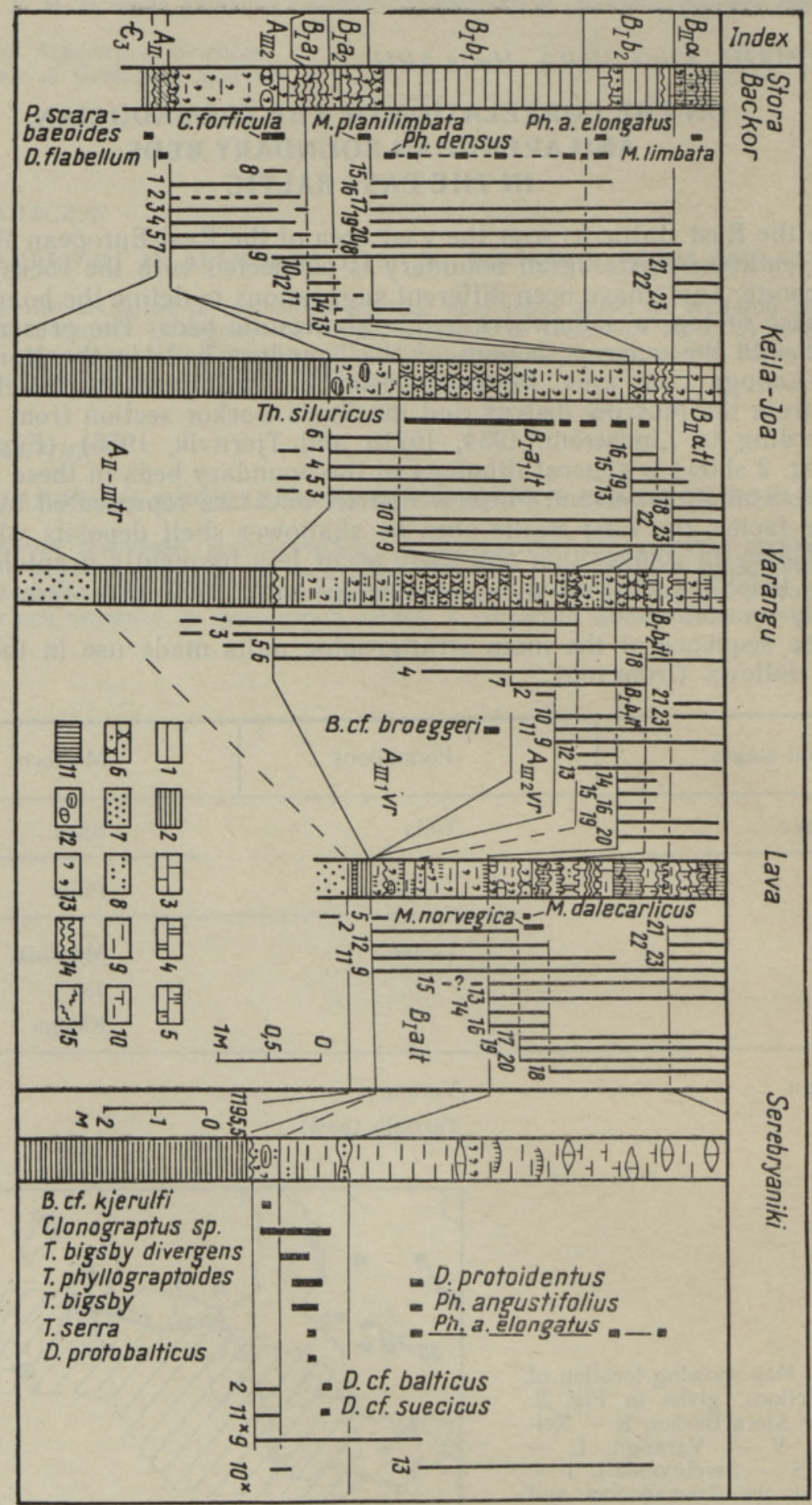


Fig. 2. Investigated sections and correlation of the Tremadocian/Arenigian boundary deposits.

Lithological legend: 1 - greenish grey argillites (shales); 2 - dark brown kerogenic argillites ("Dictyonema Shales"); 3 - limestones; 4-dolomites; 5 - dolomitic limestones; 6 - aleurolites (above) and sandstones (below); 7 - sands; 8 - aleurites; 9 - clays; 10 - marls; 11 - red coloured beds; 12 - pebbles; 13 - glauconite; 14 - discontinuity surfaces; 15 - burrows.

Conodonts: 1 - Cordylodus prion Lindstr.; 2 - Paroistodus numarcuatus (Lindstr.); 3 - Cordylodus rotundatus Pand., $4-$ Drepanoistodus acuminatus (Pand.); 5 - Cordylodus angulatus $\mathrm{Pand} ; 6-$ Drepanoistodus deltifer pristinus (Viira); $7-D . d$. deltifer (Lindstr.); 8 - Pravognathus aengensis Lindstr.; 9 - Drepanodus arcuatus Pand.; $10-$ Paroistodus proteus (Lindstr.); $10^{*}-P$. aff. proteus; 11 - Acodus deltatus Lindstr.; 11* - A. aff. deltatus (older form); $12-$ Drepanoistodus inconstans (Lindstr.); 13 - Drepanoistodus forceps (Lindstr.); 14 - Prioniodus elegans Pand.; 15 - Oistodus lanceolatus Pand.; 16 - Oepikodus evae (Lindstr.); 17 - Stolodus stola (Lindstr.); 18 - Protopanderodus rectus (Lindstr.); 19 - Scolopodus rex Lindstr.; 20 Periodon flabellum (Lindstr.); 21 - Baltonidus triangularis (Lindstr.); $22-$ Baltoniodus navis (Lindstr.); 23 - Microzarkodina flabellum (Lindstr.).

Indexes of the regional units: $\vartheta_{3}-$ Upper Cambrian; $A_{11}-$ Pakerort Regional Stage; $A_{1111}$ - lower part of Varangu Stage with Drepanoistodus deltifer pristinus Zone; $\mathrm{A}_{1112}$ - upper part of Varangu Stage with $D$. d. deltatus Zone; $\mathrm{B}_{1} \mathrm{a}_{1}$ - lower part of Hunneberg Substage with Paroistodus proteus Zone; $\mathrm{B}_{\mathrm{t}} \mathrm{a}_{2}$ - upper part of Hunneberg Substage with Prioniodus elegans Zone; $\mathrm{B}_{1} \mathrm{~b}_{1}-$ lower part of Billingen Substage with Oepikodus evae Zone; $\mathrm{B}_{1} \mathrm{~b}_{2}$ - upper part of Billingen Substage with Periodon flabellum and Oistodus lanceolatus; $\mathrm{B}_{11} \alpha$ - lower Substage of the Volkhov Stage. $\mathrm{A}_{11-111}$ tr - Türisalu Formation; $A_{11} v r$ - Varangu Formation; $B_{1}$ a It - Leetse Formation; $B_{1} b_{1}$ It - upper part of the Leetse Formation (Mäeküla Member); $\mathrm{B}_{1} \mathrm{~b}_{2} \mathrm{tl}$ - lower part of the Toila Formation (Päite Member); $\mathrm{B}_{11} \alpha$ tl - lower part of the Toila Formation in Volkhov Stage (Saka Member).

The lowermost part of the terrigenous glauconite beds studied belongs to the Varangu Formation. This is represented by grey clays with glauconitic interbeds and late Tremadocian graptolites Bryograptus and Clonograptus (Кальо, Кивимяги, 1974). According to conodonts there was established the Drepanoistodus deltifer Zone which may be subdivided into two subzones as follows (from bottom): D. deltifer pristinus and D. deltifer deltifer (Вийра et al., 1970; Szaniawski, 1980).

Higher in the East Baltic sections there follows a more sandy and silty glauconitic Leetse Formation, the major part of which corresponds to the Paroistodus proteus Zone. There occur also Paltodus inconstans and Acodus deltatus (Fig. 2), treated as belonging to the Arenigian. The lower part of the Formation (Klooga Member), especially in NW Estonia, contains some conodonts (Cordylodus angulatus, D. d. deltifer, etc.) ranging from the underlying beds.

There occur also Thysanotos siluricus (Eichwald) considered as a classical Upper Tremadocian species. It seems, however, that Polish and Czechoslovakian specimens of the species differ from the Estonian ones. This was noted already by W. Bednarczyk (1988), who has distinguished $T$. siluricus sensu lato. The conodont correlation with Swedish sections shows that glauconitic clayey sands, containing $T$. siluricus in NW Estonia, correspond to the lowermost part of the Hunneberg Substage, to the Megistaspis armata Zone.

$P$. proteus Zone is more distinct in the east (Lava outcrop, the Leningrad District), where the thickness of the Leetse Formation decreases and the forms, coming from the underlying beds, are scarce.

In the upper part of the Leetse Formation there appears at first Prioniodus elegans and then, at the base of the Mäeküla Member, Oepikodus evae and Oistodus lanceolatus together.

The thickness of the $P$. elegans Zone increases eastwards. $P$. elegans occurs together with Scolopodus rex, which is always more abundant than the zonal form. 
Generally, the $P$. elegans Zone corresponds to the D. balticus graptolite Zone which represents the boundary interval between the Hunneberg and Billingen Substages (Bergström, 1968; Lindström, 1971b; Jaanusson, 1982). We consider it most convenient to define the base of the Billingen Substage at the base of the $O$. evae Zone proceeding from the changes in fauna and a gap at this level.

At the base and the upper boundary of the beds with $P$. elegans we can find pebbles (Mäekalda section in Tallinn). In the outcrop area, at the level of the appearance of $P$. elegans and especially at the level of $O$. evae, the section becomes noticeably more carbonate.

In the Mäekalda Member the $O$. evae Zone (thickness predominantly less than $0.5 \mathrm{~m}$ ) is widely distributed. At this level articulate brachiopods, crinoids, ostracodes, and especially trilobites appear. From the Mäeküla Member the following trilobites have been identified: Megalaspides dalecarlicus, M. paliformis, M. norvegica, characterizing Billingen Substage, but also the early representatives of Encrinuroides, Cybele, Krattaspis, Pliomera, Remopleurides (?), Panderia.

Conodont species of the Billingen Substage $O$. lanceolatus and Periodon flabellum range from the Mäeküla Member to the abovelying limestones and dolomites of the Päite Member of the succeeding Toila Formation.

The lower boundary of the Volkhov Stage is marked by the appearance of Microzarkodina flabellum, Baltoniodus triangularis and $B$. navis in the following Saka Member of the Toila Formation.

The Tremadocian/Arenigian boundary beds in the Baltic-Ladoga clint area forms a glauconite-containing sedimentary cycle starting with clays of the Varangu Formation (Upper Tremadocian), turns then into clayey silts and sands in Lower Arenigian and more sandy Leetse Formation in the Middle Arenigian. All over the East Baltic area facies conditions were more or less similar, but, due to gaps, the sequences of the lithostratigraphic units are different. Most complete sections are as follows (Fig. 2): Varangu Formation in middle North-Estonia, Hunnebergian part of the Leetse Formation in NW Estonia, Billingenian part of that formation and of the base of the Toila Formation in NE Estonia and the Leningrad District.

The greatest changes in the facies fauna of the studied sections took place: 1. at the base of the Varangu Formation (base of the D. deltifer pristinus Zone), 2. at the base of the Mäeküla Member (upper part of the Leetse Formation, base of the $O$. evae Zone). The latter marks the beginning of the Ordovician and Silurian long-term carbonate sedimentation in the East Baltic.

\section{R E F E R E N C E S}

Bednarczyk, W. Rola brachiopodów inarticulata w stratygrafii najnižszego ordowiku Gór Swiętokrzyskich // Przegląd geologiczny. Wydawnictwa Geologiczne. Warszawa, 1988, N 1, 17-23.

Bergström, S. M. Biostratigraphy of the Lower Ordovician sequences at Skattungen, Dalarna // Geol. Fören. Stockh. Förh., 1968, 90, N 454.

Jaanusson, $V$. Introduction to the Ordovician of Sweden // Field Excursion Guide IV Intern. Symp. Ordovician System. Univ. Oslo Paleont. Contr., 1982, N 279, 1-9.

Lindström, $M$. Conodonts from the lowermost Ordovician strata of South-Central Sweden // Geol. Fören. Stockh. Förh., 1954, N 479, 517-604.

Lindström, M. Ordovician conodont-bearing sections in Sweden. Symposium on conodont taxonomy. A field trip guidebook. Pre-Symposium Excursion, Sept. 4-11, 1971. Marburg/Lahn, $1971 a$.

Lindström, M. Lower Ordovician conodonts of Europe // Geol. Soc. Am. Mem., 1971b, N $127,21-61$. 
Szaniawski, $H$. Conodonts from the Tremadocian chalcedony beds. Holy Cross mountains (Poland) // Acta Palaeont. Polonica, 1980, 25, N 1, 101-121.

Tjernvik, T. E. On the Early Ordovician of Sweden Stratigraphy and Fauna // Bull. Geol. Inst. Univ. Upps., 1956, 36, 107-284.

Вийра В., Кивимяги Э., Лоог А. О литологии и возрасте варангуской пачки (тремадок Северной Эстонии) // Изв. АН ЭССР. Хим. Геол., 1970, 19, № 2, 147-155.

Кальо Д. Л., Кивимяги Э. К. Зональное расчленение тремадока Эстонии // Граптолиты и стратиграфия. Таллин, 1976, 56-63.

Academy of Sciences of the Estonian SSR,

Received Institute of Geology

Jan. 18,1989

Silvi MÁGI, Viive VIIRA, Helje ARU

\section{BALTIKUMI TREMADOCI JA ARENIGI PIIRIKIHTIDE KORRELATSIOONIST}

On iseloomustatud Tremadoci ja Arenigi piirikihte Põhja-Baltikumi avamusala tugiläbilöigetes, kus nad on seotud Varangu ja Leetse kihistute terrigeen-glaukoniitsete setetega. Konodontide ja ka graptoliitide leviku põhjal on neid korreleeritud Stora Backori tugiläbilõikega (Skandinaavia) ja Serebrjaniki puursüdamikuga (Moskva sünekliisi lōunaosa).

\section{Сильви МЯГИ, Вийве ВИИРА, Хелье АРУ}

\section{О КОРРЕЛЯЦИИ ПОГРАНИЧНЫХ ОТЛОЖЕНИЙ ТРЕМАДОКА И АРЕНИГА ПРИБАЛТИКИ}

Пограничные отложения тремадока и аренига в районе выхода вдоль ЭстонскоЛадожского глинта связаны с терригенно-глауконитовыми отложениями варангуской и леэтсеской свит на границе вендо-кембрийского терригенного и ордовикско-силурийского карбонатного комплексов пород. По распределению конодонтов, а также граптолитов проводится их корреляция с более терригенным опорным разрезом Стура Бакор в Скандинавии и с разрезом скв. Серебряники в южной части Московской синеклизы (рис. 1, 2). Дается первоначальный список трилобитов, появляющихся в базальных слоях карбонатных отложений, связанных с конодонтовыми зонами Prioniodus elegans и Oepikodus evae. 